\title{
THE LABORATORY PRODUCTION OF SOLAR IRON LINES \\ IN THE VACUUM ULTRAVIOLET
}

\author{
by Lewis I. Houst \\ (High altitude Observatory, Boulder, Colorado U. S. A.)
}

Résomé. - En utilisant la machine à plasma de Los Alamos dont les parois sont en céramique et en y introduisant des impuretés connues, on a pu produire certaines raies du spectre solaire, dans la région 150-220 A. Ces raies semblent émises par des atomes de $\mathrm{Fe}$ ionisé ( $F e X \grave{a} F e X I V)$.

ABstract. - The Scylla plasma which is contained in a ceramic discharge tube has been purposely contaminated with known impurities. The spectrum of the discharge with $\mathrm{Fe}(\mathrm{CO})_{5}$ added shows most of the solar lines in the 150-220 A region. Some of these strong lines may be produced by iron in intermediate stages of ionization (Fe X to Fe XIV).

Резюме. - Используя плазмовую машину в Лос Аламос, стенки которой фарфоровые, и вводя в нее известные посторонние примеси, удалось воспроизвести некоторые линии солнечного спектра в области 150-220 А. Эти линии по-видимому излучены атомами ионизированного железа (Fе X до $\mathrm{Fe} \mathrm{XIV}$ ).

The solar spectrum in the extreme ultraviolet, as observed by Hinteregate [1], BeHrina, NeUPERT, and LINDSAY [2], and TOUSEY, AUSTIN, PURCELl, and Widna [3], contains many unidentified lines. A group of lines in the range 150-220 are especially strong. Recent observations of the Zeta spectrum [4] have shown a coincidence between the laboratory lines and several of the strong solar lines. Many of the lines are presumably iron because the plasma is contained in a stainless steel tube. The work reported in this paper gives further evidence as to the nature of these lines.

The technique we use to excite and observe the spectra of highly ionized atoms has been described previously [5]. Briefly stated, the method is to add impurities to a high temperature theta-pinch plasma device and observe the time integrated radiation photographically. The spectra with and without impurities are compared to show the presence of new lines. This experiment has been carried out at the Los Alamos Scientific Laboratory in cooperation with Dr. George A. SAwYER and use is made of the Scylla III plasma [6]. The spectrograph is a 2-meter grazing incidence rocket spectrograph [7] loaned to us by Dr. H. E. HinTeREGGER of Air Force Cambridge Research Laboratories.

Since the Scylla plasma is contained in a ceramic discharge tube, it offers the possibility of independently introducing iron into the plasma, thus confirming or rejecting the iron identification for the lines common to the sun and laboratory. As reported by $R$. WILson and R. Tousey at this meeting, similar experiments have been conducted at the Culham Laboratory and the Naval Research Laboratory respectively.

Figure 1 shows the basic spectrum of the Scylla discharge without impurities added. The lines belong to elements present in the ceramic and stages of ionization such as $\mathrm{Si} V$ through $X$ and $O$ IV through VII are observed. In figure 2 a portion of two spectrograms show the basic Seylla spectrum (A), compared to the spectrum taken with $\mathrm{Fe}(\mathrm{CO})_{5}$ (iron pentacarbonyl) added to the plasma (B). It is quite clear that several new lines are produced when the iron is added. In figure 3 a tracing of the 150-220 $\AA$ region is shown. The top tracing is the basic spectrum, the middle the spectrum with iron added, and the bottom a photoelectric recording taken by HINTEREGGER. The lines marked with a caret are due to iron. When the Scylla spectra with iron added is compared to the Zeta spectra, the common iron lines agree to within $0.02 \AA$.

The experiment indicates that the lines are likely of intermediate stages of ionization of iron for the following reason. The $\mathrm{O}$ VI and $\mathrm{O}$ VII lines at $128 \AA$ provide some indication of the temperature attained. When the $O$ VII line is strong compared to $\mathrm{O} \mathrm{VI}$, indicating high temperatures, the iron lines are significantly weakened or not present. On the other hand, at lower temperatures as indicated by $\mathrm{OVI}$ being at least as strong as $O$ VII the iron lines likewise become strong. 
It is believed that some of the lines may belong to the $3 p$ to $3 d$ and $3 d$ to $4 d$ transitions in $\mathrm{Fe} \mathrm{X}$ to $\mathrm{Fe}$ XIV [8].

Additional work is in progress both theoretically and in the laboratory to attempt to complete the identification of these strong solar lines.

Manuscrit reçu le 20 septembre 1964.

\section{REFERENCES}

[1] Hinteregger H. E., 1963, Symp. on the Solar Spectrum, Utrecht.

[2] Behring W. E., Neupert W. M. and Lindsay J. C., 1962, Proc. Third Int. Space Sci. Symp., Washington, D. C., 814.

[3] Tousey R., Austin W. E., Puroell J. D. and WidINg U. G., 1962, Proc. Third Int. Space-Sci. Symp., 772.

[4] Fawcett B. C., Gabriel A. H., Griffin W. G., Jones B. B. and Wilson R., 1963, Nature, $200,1003$.
[5] Hodsw L. L. and Sawyer G. A., 1964, Ap. J., 139, 775 .

[6] LitTle E. M., QuinN W. E., Ribe F. L. and SAWYer G. A., 1962, Nuclear Fision, Suppl., Part 2, 497.

[7] Hinteregaer H. E., 1961, Space Physics, ed. W. Liller (New York : McGraw-Hill Book Co.), 34.

[8] ZIrIN H., Private Communication. 